\title{
Novena (1964) de Milton Nascimento e Márcio Borges: primórdios da síntese do Clube da Esquina
}

\author{
Fausto Borém (UFMG, Belo Horizonte, MG) \\ fborem@ufmg.br
}

Wilson Lopes (UFMG, Belo Horizonte, MG)

lopes.ww@gmail.com

Resumo: Análise de Novena, canção de 1964 que inaugurou a carreira de compositores da dupla do então cantorinstrumentista Milton Nascimento e do letrista Márcio Borges. 0 contexto histórico, especialmente a partir de depoimentos dos dois artistas (BORGES, 1996, 2010, 2012; NASCIMENTO, 1993, 1996, 2009, 2012; BORGES e NASCIMENTO, 2012a, 2012b, 2012c, 2012d, 2012e, 2012f, 2012g, 2012h, 2012i, 2012j) e elementos melódicos, harmônicos e da relação textomúsica da canção, percebidos na transcrição da única gravação de Milton Nascimento (NASCIMENTO e BORGES, 1993), apontam para a sintese de uma estética que se consolidou no Clube da Esquina, cujos membros desenvolveram carreiras com perfis ecléticos e uma linguagem musical estilisticamente híbrida.

Palavras-chave: Milton Nascimento e Márcio Borges; Clube da Esquina; música popular brasileira; música, cinema e política; análise estilística da música popular.

\section{Novena (1964) by Milton Nascimento and Márcio Borges: hybridism in the compositional premiere of Clube da Esquina}

Abstract: Analysis of Novena, a song from 1964 that launched the career, as composers, of the singer-instrumentalist Milton Nascimento and lyricist Márcio Borges. The historical context, especially that told by the artists (BORGES, 1996, 2010, 2012; NASCIMENTO, 1993, 1996, 2009, 2012; BORGES e NASCIMENTO, 2012a, 2012b, 2012c, 2012d, 2012e, 2012f, 2012g, 2012h, 2012i, 2012j) and melodic, harmonic and text-painting elements, observed in the transcription of the only and late recording by Milton Nascimento (NASCIMENTO and BORGES, 1993) point out to a synthesis of an aesthetics that consolidated into the Brazilian Clube da Esquina (Corner's Club), whose members developed careers of eclectic profiles and a stylistically hybrid musical language.

Keywords: Milton Nascimento and Márcio Borges; Clube da Esquina (Corner's Club); Brazilian popular music; music, cinema and politics; musical analysis of popular music.

Os co-autores agradecem a leitura e sugestões de Milton Nascimento no presente artigo.

\footnotetext{
De repente, abre-se a porta e quem aparece? JEANNE MOREAU !!! ... Conte minha vida até JULES ET JIM e mais. Fui surpreendido com a seguinte frase da minha diva: "Como é bela a arte, Milton! Trabalhamos numa coisa aqui e vamos tocar a alma de quem nem sabemos e nem onde. Ontem fui eu, Truffaut, e agora é você. Que lindo e que responsabilidade!" Ela disse isso chorando... 0 Clube da Esquina continua vivo nas músicas, nas letras, no nosso amor, nos nossos filhos e quem mais chegar... (Milton NASCIMENTO, 1996).

... eu sei que influenciei muito o Bituca, mas sei também que ele me influenciou em dobro; porque o Bituca é o Sol e eu sou a Lua... (Márcio BORGES, 2012)
} 


\section{1 - Milton Nascimento, Márcio Borges e - Clube da Esquina: aqui se toca, canta, transcreve, arranja, compõe e faz poesia}

Era uma tarde de 1964 na vida dos amigos Manículas Prospectus e Das Baixínhans (Ex.1), apelidos com os quais se divertiam os rapazes Milton Nascimento e Márcio Borges na juventude, devido ao tamanho das mãos do primeiro e baixa estatura do segundo (BORGES, 1996, p.28). Uma tarde que eles não sabem precisar de qual mês ou dia. Uma tarde que entrou noite adentro, após os dois assistirem a três sessões seguidas do filme Jules et Jim do cineasta francês François Truffaut no Cine Metrópole, em Belo Horizonte, ${ }^{1}$ e sentirem uma grande urgência de se tornarem compositores de canções populares (BORGES, 1996, p.57-59). Esse foi o início de uma parceria artística que já completou 50 anos. Márcio Borges já havia assistido à pré-estreia do filme, da qual saiu com uma missão: "Queria criar também, desejava naquele momento fazer muitos filmes tão lindos quanto esse" (BORGES, 1996, p.44). Passou essa tarefa também para Milton Nascimento: "Você tem é que compor. Pára de cantar coisas dos outros! A coisa mais rara do mundo é originalidade. E isso você tem de sobra. Você é um compositor" (BORGES, 1996, p.45). Na época de Jules e Jim, Milton se considerava apenas cantor e havia se tornado contrabaixista do Trio Berimbau, juntamente com Wagner Tiso e Paulinho Braga, para complementar seu salário de datilógrafo de escritório.

Do cinema foram direto para o "quarto dos homens" do apartamento no Edifício Levy (Ex.2), quarto onde dormia a maioria dos 11 filhos da família Borges. Ali, se debruçaram sobre o exercício de compor incessantemente. Márcio, a letra. Milton, a música. Simultaneamente. Milton disse a Márcio:

\begin{abstract}
"... 'Pega lápis e papel que nós vamos compor é agora', eu peguei o lápis e o papel e ele começou: "tan, $\tan , \tan , \tan , \tan , \tan$, tendondontundun, dun, dun... ", que é o próprio Jules e Jim, era o clima que a gente tinha acabado de viver. Era aquilo mesmo. Era a tradução do Bituca daquele clima, entende, filtrado por aquele cara que era o Bituca (BORGES, 2010).
\end{abstract}

Fecharam a noite com três músicas, finalizadas ali mesmo, e um grande compromisso entre eles:

"... nos deu uma certeza de que uma nova história começava a
se escrever ali mesmo para nós, e que as eras poderiam se dividir,
a partir deste fato consumado, em A.J.J. e D.J.J.; isto é, Antes de
Jules e Jim e Depois de Jules e Jim. Sairam três músicas nesta
noite: Paz do amor que vem (Novena), Gira-girou e Crença... as
recém-nascidas filhas, como chamávamos as músicas que iamos
criando " (BORGES, 1996, p.60)

De seu lado, ainda em Três Pontas, Milton já havia percorrido uma rica trajetória na sua formação musical. Ele fala sobre as influências da formação erudita e gosto diversificado da mãe, que tinha sido aluna de Villa-Lobos no Rio de Janeiro (BORGES e NASCIMENTO, 2012g, Pais adotivos: música e astronomia) e ouvia de ópera a jazz:

\begin{abstract}
"... [Márcio Borges] tinha de um lado a dona Lília, uma pessoa urbana, de outro o seu Zino, uma pessoa interiorana. Um com a mentalidade científica... [Bituca] Aguçada! [Márcio Borges] ... e a outra com um temperamento totalmente artístico, né, porque a dona Lilia só não foi artista porque a vida não deu a ela essa chance, né, mas deu ao seu filho. [Bituca] E era uma coisa muito linda também, porque a gente tinha os discos de operetas, música clássica, temas de filmes e também a gente com os amigos partíamos pra música popular brasileira, essas coisas todas. Tinha os discos das cantoras de jazz com grandes bandas... Então, lá em casa sempre ouvi de tudo" (BORGES e NASCIMENTO, 2012i, Uma família eclética).
\end{abstract}

Desde a mais tenra idade, Milton soube transformar as limitações que encontrava ao fazer música em estímulos à sua criatividade, em desafios lúdicos:

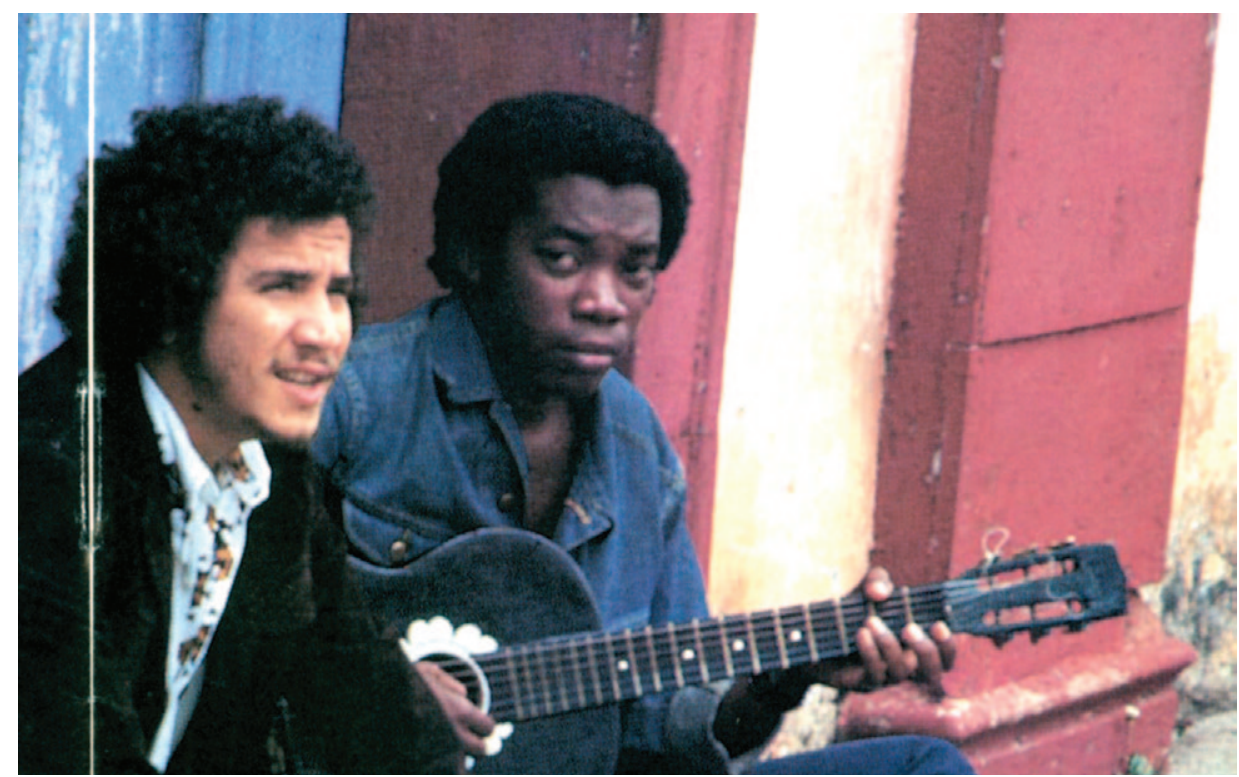

Ex.1 - Márcio Borges (Das Baixínhans) e Milton Nascimento (Manículas Prospectus): amigos que se tornaram compositores da pedra fundamental do Clube da Esquina em 1964 (Na foto, nas ruas de Diamantina em 1971; BORGES, 1996, p.364-365).2 


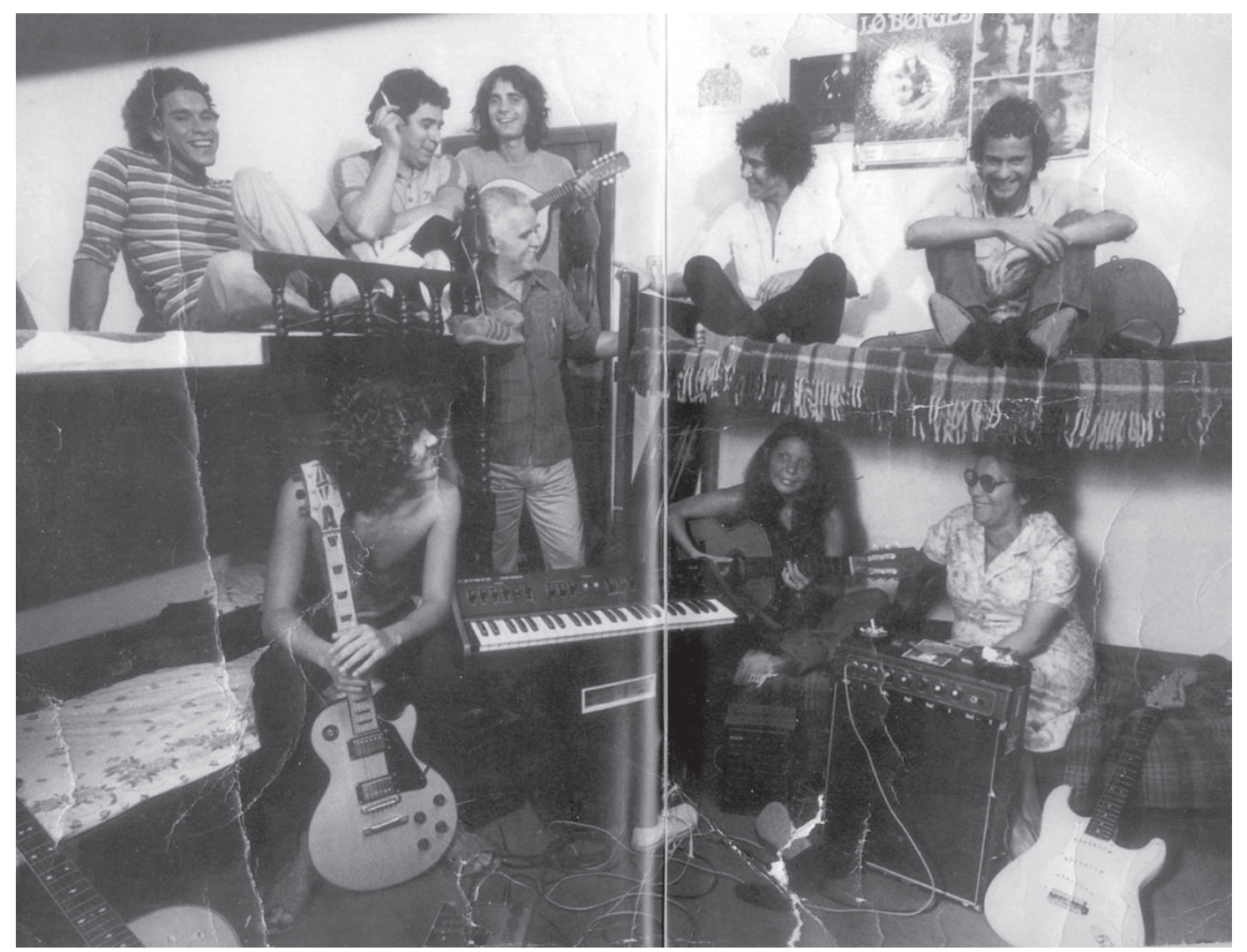

Ex.2 - 0 "quarto dos homens" no apartamento da família Borges no Edifício Levy em Belo Horizonte, onde foram compostas Novena, Gira-girou e Crença, as três primeiras canções de Milton Nascimento e Márcio Borges. (Na foto de família, em cima, Telo, Marilton, Lô, o pai Salomão, Márcio e Yé. Em baixo, Nico, Solange e a mãe Dona Maricota. Faltam ainda as irmãs Sandra, Sônia, Sheila e Suely; BORGES, 1996, p.366-367).

Antes de completar sete anos ganha uma gaita e uma sanfona de quatro baixos. Passa horas sentado na varanda de casa, tocando os dois instrumentos ao mesmo tempo, com ajuda dos joelhos para segurar a gaita. Como a sanfona era precária, completa as notas que faltam com o som da voz (NASCIMENTO, 2012, site oficial).

Aos 13 anos, já tocando o violão que a mãe ganhou de presente e sempre ao lado de Wagner Tiso, participou da formação de conjuntos como Luar de Prata, Milton Nascimento e seu Conjunto e o W's Boys. ${ }^{3}$ Desde o início dessa efervescente adolescência em Três Pontas, com o amigo Wagner Tiso, Milton já praticava a transcrição musical e o arranjo, ainda sujeitos às restrições tecnológicas da época:

"E aí tinha o movimento da bossa nova, tinha o do rock- $n$ '-roll, tinha coisa acontecendo adoidado, tango e tudo que tinha. E quando começou a bossa nova, a gente pegava as músicas pelo rádio, e aí tinha a cantora, que era a Tereza Sacho. E ela, quando começava uma música que a gente estava gostando, pegava a caneta e ia escrevendo a letra do jeito que dava, ou eu também. $E$ eu e Wagner íamos pegando a melodia, porque a harmonia era a coisa mais difícil de ouvir, porque o rádio era muito ruim. Às vezes até a gente só ia ouvir essa música outra vez um mês depois, ou dois meses, e tal. Então, quando a gente ia ouvir essa música, a gente já tinha feito a harmonia da nossa cabeça, né. E assim foi o nosso começo." (BORGES e NASCIMENTO, 2012a, A Familia cresce e Bituca desiste de ser economista)
Surpreendente, no entanto, é a maneira como os dois transformaram essas limitações a seu favor, ampliando as possibilidades harmônicas em função da dúvida. Mas a consciência da flexibilidade de re-harmonização e da improvisação na linha melódica, que mais tarde eles encontrariam ecos no jazz e influenciariam seus colegas do Clube, veio aos poucos:

... [Márcio Borges] essa coisa que anos mais tarde veio a ser reconhecida como uma originalidade, né, porque você quando apareceu, apareceu como uma coisa original. [Bituca] Eu acho que tudo vem disso aí. [Márcio Borges] Talvez se vocês tivessem pegado as harmonias todas certinhas... [Bituca] Ah, não, aí não. Seria outra coisa. E uma coisa muito interessante, é que quando eu tive assim o meu primeiro contato com músicos profissionais de cidade grande, foi lá em Belo Horizonte, então a gente foi no Berimbau, né, que é o lugar onde o pessoal se apresentava. Então a gente foi assistir ao show de um grupo lá e eu quase caí pra trás, porque eles tocaram músicas que eu e Wagner tocávamos, mas de uma maneira completamente diferente da nossa. E eu peguei, fiquei desesperado. Falei: "Pô! Tenho que aprender tudo de novo!" E ai nessa época eu tocava com Marilton, seu irmão, e o Marcelo Ferrari, o Turinha, que era um puta percussionista. E depois eu fui conhecendo o pessoal, mas desde que saí, cabisbaixo, que eu falei pro Marilton: "eu tenho que mudar tudo, tenho que aprender tudo de novo", ai Marilton falou: "você está louco! Tem que tocar desse jeito aí." [Márcio Borges] Está muito melhor do que o original... [Bituca] o Blue Moon que todo mundo toca de um jeito, o Wagner chegou tocando, parecia que ele estava tocando 
a música de trás pra frente, porque Blue Moon é em maior e ele tocava numa sequência menor, com não-sei-quê, aquele negócio todo. Por exemplo, no Rio ele ficou sendo conhecido como o pianista do Blue Moon... " (BORGES e NASCIMENTO, 2012b, A Marca da originalidade).

Da experiência de transcrever e arranjar música, Milton e Wagner Tiso passaram à composição. Em "... uma das maiores entrevistas que Milton Nascimento já concedeu em sua vida... quase cinco horas de gravação" (BORGES e NASCIMENTO, 2012d, Introdução), ele fala de suas primeiras experiências de compor:

\begin{abstract}
"As primeiras músicas que eu fiz foi com Wagner [Tiso] e depois com um outro rapazinho de Belo Horizonte, Noite Vazia, uma coisa assim, que era até muito bonita. Mas essas músicas que a gente compunha era uma coisa assim, muito de criança... " (BORGES e NASCIMENTO, 2012h, Surge o compositor).
\end{abstract}

Em 1963, mudou-se para uma pensão no Edifício Levy em Belo Horizonte, integrando grupos como o conjunto de baile de Célio Balona e o Conjunto Holliday. Márcio Borges lembra como a música romântica anterior à bossa nova fazia parte dessa cultura: "Trazíamos em nossas bagagens Ângela Maria, Cauby Peixoto ... Trio Los Panchos, boleros, twists e chachachás... " (REVISTA E ONLINE, 2009), cultura da qual participava até Nelson Ned, que frequentava a casa dos Borges (BORGES, 1996, p.49) e se tornaria um dos ícones da música popular romântica no Brasil e no exterior. Os parceiros de Novena lembram das referências que decoravam a boate Berimbau:

\footnotetext{
"... uma das casas mais geniais que já existiram em Belo Horizonte, num dos pontos mais geniais que já existiram neste planeta, que foi o [Edifício] Maletta dos anos [19]60, que foi um foco de cultura e de revolução e que saíram grandes talentos dali... [Bituca] Tinha os retratos na parede, né. [Márcio Borges] Eu lembro que tinha um retratão de Jorge Ben... [Bituca] Miles Davis, Modern Jazz Quartet, John Coltrane... " (BORGES e NASCIMENTO, 2012j, Vinícius e Berimbau).
}

Silvio Essinger (citado por SZAJMAN, ed., 2009) também menciona a interação de estilos diversos e aparentemente contraditórios no estilo emergente de Milton:

\footnotetext{
"... bossa nova, Beatles, toadas, congadas, choro, jazz, folias de reis e rock progressivo, tudo reunido numa música original, de apelo universal... fundia as inovações trazidas pela Bossa Nova a elementos do jazz, do rock'n'roll ... The Beatles -, de música folclórica dos negros mineiros e alguns recursos de música erudita e música hispânica."
}

Em 1964, com Wagner Tiso e Paulinho Braga, criou o Berimbau Trio, onde fez sua estreia como contrabaixista e com o qual participou da gravação do LP Quarteto Sambacana de Pacífico Mascarenhas (NASCIMENTO, 2012, site oficial), que foi um pioneiro da bossa-nova em Minas Gerais. Com o Conjunto Holliday, Milton desenvolveu suas habilidades de crooner ("... A gente tocava muito no [Clube] Cruzeiro... ", BORGES e NASCIMENTO, 2012f, Nos bares da vida) e gravou o compacto Barulho de Trem (NASCIMENTO, 2012, site oficial), canção com música e letra de sua autoria e que já era cantada pelo irmão mais velho de Márcio Borges, Marilton, na casa de Seu Salomão, patriarca dos Borges (BORGES, 1996, p.22).
Um pouco mais tarde, ele viveu a experiência marcante de acompanhar Vinícius de Morais em Belo Horizonte, quando teve a oportunidade de lhe mostrar canções e vislumbrar o que estava sendo feito fora das Minas Gerais:

\begin{abstract}
"... o Hélvius [Vilela] apareceu lá na pensão onde eu morava e falou: "Bituca, você tem que ir pra substituir a gente de qualquer jeito, porque a gente não pode deixar furo, tocar com Vinicius de Moraes..." Eu fiquei maluco. "Tocar com Vinícius de Moraes, que doideira!" Aí cheguei, me apresentei pro Vinícius, ai começou aquele show dele, a palestra dele com os estudantes, aquele célebre copo de uísque, a mesinha, e ele falava e cantava as músicas e eu acompanhava no violão. [Milton acrescenta o seguinte nessa citação: ... Uma hora ele perguntou aos estudantes se sabiam de alguém novo na música popular mineira e eles apontaram o dedo para $\mathrm{mim}$ ] . . eu acabei tocando umas músicas minhas [grifo nosso]... [Milton acrescenta: inclusive me lembro da primeira que foi '... E a gente sonhando']... a gente saiu pelas noites, fomos tocar nuns bares com o Vinícius e tinha um arranjo que eu tinha feito pra Marcha da Quarta-Feira de Cinzas [Milton acrescenta: para um quarteto vocal feminino] ... com a harmonia que eu tinha criado, aquele negócio todo, e a gente cantou e o Vinícius cantando com a gente...Foi uma coisa linda, uma noite que só acabou acho que dez horas da manhã do outro dia. Isso foi uma coisa marcante." (BORGES e NASCIMENTO, 2012j, Vinícius e Berimbau).
\end{abstract}

Milton também fala de Aconteceu, outra de suas primeiras canções anteriores à fase em que ele se considera compositor. Quando foi ao Rio gravar o disco Muito pra frente (Odeon, 1965) com o grupo Quarteto Sambacana de Pacífico Mascarenhas, ele lembra de como essa canção marcou Elis Regina:

\footnotetext{
"... a gente veio pro Rio, eu, Wagner e Pacífico [Mascarenhas], fomos num estúdio, onde estava o Moacir Santos [Milton acrescenta nessa citação: que tinha feito arranjos para uma cantora chamada Luiza]... ele [Pacífico] queria que eu e Wagner tocássemos de qualquer maneira numa festa onde estavam quase todos os nomes do pessoal da bossa nova. Eu falei: "Eu não toco aqui nem...."; eu sempre assim, né? Acabei pegando o violão, e o Wagner o piano e a gente tocou uma música nossa, Aconteceu [grifo nosso]... nessa festa, estava a Elis Regina, que tinha acabado de chegar do Rio Grande do Sul [Milton acrescenta nessa citação: e gravado um disco de rock] ... cheguei no carro dela e comecei a cantar uma das músicas daquele disco, ela: "Sshhh!!! Cala essa boca! Esquece isso!" [Milton acrescenta nessa citação: E eu saí correndo]...
}

... [anos depois] quando eu estava em São Paulo, no Berimbau de Ouro ... ouço um barulho de sapato! PAM! Ela falou: "Escuta, mineiro não tem educação, não?" Aí, eu parei, olhei e não tinha mineiro nenhum mais, né? Ela falou assim: "Olha, as pessoas, que tem educação fazem o seguinte: quando a gente se encontra assim de manhã a gente fala "bom dia", quando é de tarde a gente fala "boa tarde" e quando é de noite, a gente fala "boa noite". Aí, eu vermelho feito não sei quê, falei: "Não, Elis, é que eu não queria te perturbar..." Ela: "Não tem nada disso não. Eu quero que você vá lá em casa pra cantar aquela música que você cantou naquela festa na casa da [cantora] Luiza. E começou a cantar Aconteceu [grifo nosso]. Isso era uns três ou quatro anos depois. Ai eu fiquei olhando pra ela assim, tipo babando. Ela pegou, falou assim: "Memória, meu caro, memória." E saiu balançando aqueles tamancos dela." (BORGES e NASCIMENTO, 2012h, Surge o compositor).

Se Milton Nascimento chegou ao histórico tríptico formado por Novena, Crença e Gira girou com relativa bagagem musical, Márcio Borges também tinha, em casa, uma valiosa experiência na qual podia se ancorar:

A música, na minha vida, entrou através de Marilton [Borges] ... Essa penca de músicos que tem lá em casa... tudo vem dele ... Ele levou esse disco ... era acetato ainda... "Chega de Saudade", do 
João Gilberto - foi a primeira música de verdade que entrou lá em casa. E nós nos apaixonamos imediatamente... " (BORGES, 2012).

E também o gosto pela literatura, desde muito cedo, povoado por obras como Tesouro da juventude e os livros de Júlio Verne:

\begin{abstract}
Pelo fato de eu ter passado pela infância um pouco doente... então eu estava sempre lendo, que é uma coisa boa de fazer sozinho... Tinha rádio e livro, que era onde a gente buscava informação... lá em casa, eu era o que tinha mais pendor pra ler. Eu é que embarcava mais nessa de ler - Marilton com a música e eu lendo... E de ler pra querer escrever é um passo... crônicas, contos, versos, observações esparsas, pedaços de frases que eu ia escrevendo e jogando dentro da mala... (BORGES, 2012).
\end{abstract}

Seu pai, Salomão Borges, era jornalista e, após descobrir e "devassar" o conteúdo da mala escondida debaixo da cama, levou um dos textos do filho para o também jornalista e escritor Roberto Drummond, que reagiu com desconfiança:

\begin{abstract}
... "Qual é, Salomão? Fica escrevendo as coisas pro seu filho pra falar que é ele? Que maneira mais indiscreta de me pedir um emprego!"... Trinta e tantos anos depois, um belo dia, o Roberto Drummond escreveu uma crônica, pouco tempo antes de ele falecer, no "Estado de Minas", lindíssima, chamada "Mea Culpa", na qual ele contava essa história, falando assim: "Ainda bem que eu não dei emprego pra esse garoto, porque senão ele não tinha seguido o caminho da música e ia ser um jornalista como eu" (BORGES, 2012).
\end{abstract}

$\mathrm{Na}$ sua poesia, Márcio Borges desenvolveu um estilo econômico para falar dos sonhos e do cotidiano. São palavras cuidadosamente escolhidas, colocadas lado a lado, gerando uma narrativa não-linear e aparentemente desconexa, mas prenhe de significado. Por isso, são significativos os autores dos dois excertos que escolheu para epígrafes do seu livro Os sonhos não envelhecem: histórias do Clube da Esquina (BORGES, 1996, p.17): o escritor argentino Jorge Luis Borges (ícone do surrealismo literário) e o cineasta francês François Truffaut (ícone do movimento nouvelle vague).

0 ecletismo que se observa em Novena antecipa o ecletismo da maioria dos membros do Clube da Esquina, no qual passaram a integrar as funções de compositor, arranjador, letrista, instrumentista e cantor. Além de Milton Nascimento, destacamos: Lô Borges, Beto Guedes, Toninho Horta, Tavinho Moura, Fernando Brant, Ronaldo Bastos, Flávio Venturini, Tavito, dentre outros. $\mathrm{Ou}$ ainda alguns que se destacaram como compositores e instrumentistas, como Wagner Tiso, Nivaldo Ornellas, Nelson Ângelo, Túlio Mourão, Robertinho Silva, dentre outros. Milton fala de como as dificuldades musicais de sua infância contribuíram para seu ecletismo:

\footnotetext{
... [Bituca] "...o que eu queria mesmo é ter um piano, mas a gente não tinha dinheiro nem pra ter o piano, nem pra ter o acordeon. Então eu acabei ganhando uma sanfoninha de quatro baixos; não, primeiro foi uma de dois baixos incrivelmente terrivel, e depois uma de quatro baixos, um pouco menos terrivel, mas não tinha os acidentes. Então, quando eu começava a tocar e não tinha a nota que eu queria, eu fazia com a voz o som... [Márcio Borges] Completava. [Bituca] É, fazia o som; aliás não lembro como eu conseguia fazer aquilo, o som da nota que estava faltando na sanfoninha.." (BORGES e NASCIMENTO, 2012g, Pais adotivos: música e astronomia).
}

... [Bituca] "... eu pegava a sanfona e a gaita, sentava na frente da varanda, punha a sanfona perto do meu pé, a gaita no joelho e ficava tocando aqueles negócios lá, do jeito que eu sabia... " (BORGES e NASCIMENTO, 2012e, Meninos tocando clandestinos)

A necessidade forjava o instrumentista, que não tinha tempo ou dinheiro para investir em uma formação profissional ideal, como aconteceu com a a entrada do contrabaixo na sua vida $($ Ex.3a,b):

... [Bituca] "... o Wagner chegou e falou: "Bituca, nós fomos contratados pra tocar no Berimbau"... o máximo de Belo Horizonte. Aí eu fiquei muito feliz, aí ele falou assim: "só que você vai tocar contrabaixo. (risos) E nós vamos começar hoje." Aí eu falei: "Wagner, você está maluco, eu nunca toquei um contrabaixo na minha vida, não sei nem como é que pega naquilo e você quer pra hoje?" (risos) Ele falou: "é hoje, porque senão a gente não pega esse negócio. Se vira, sai atrás de quem tenha contrabaixo, pegue emprestado... " Eu fui atrás do Ildeu (Lino Soares), que tinha uns dois ou três contrabaixos... "Ildeu, como é que pega nisso?" ele pegou, fez umas três posições diferentes lá. Ai eu aprendi e fui pro Berimbau de noite... nos primeiros dias o sangue escorria dos meus dedos assim, não adiantava botar esparadrapo nem nada que o sangue estava correndo. Depois foi melhorando e eu fui pegando gosto pela coisa e eu acho que foi um dos instrumentos que eu

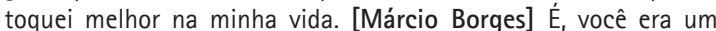
grande contrabaixista. [Bituca] Muito obrigado. E tinha uma coisa também que eu fazia com o contrabaixo que mais tarde foi usado por outras pessoas, né, que era tocar o contrabaixo e emitir notas pela boca também, junto, em alguns solos, né. E a gente criou um trio completamente diferente de tudo que acontecia, acho que em qualquer parte do Brasil. Talvez se assemelhasse assim, bem de longe, ao Tamba, mas bem de longe. (BORGES e NASCIMENTO, 2012j, Vinícius e Berimbau)

Ainda em relação à música instrumental, um traço marcante na performance de Milton Nascimento é a utilização de sua voz como se fosse um instrumentista. Desde o início de sua carreira, houve versões instrumentais de suas músicas, a exemplo de ...E a gente sonhando, gravada pelo Tempo Trio (Helvius Vilela, piano; Pascoal Meirelles, bateria; Paulo Horta, contrabaixo) em 1966 (NASCIMENTO, 2012, site oficial), mesmo ano em que Elis Regina gravou sua Canção do Sal. Já Clube da Esquina N.2 surgiu apenas como tema instrumental e só depois ganhou letra, a pedido de Nana Caymmi para Márcio Borges (BORGES, 1996, p.336). Outras, como Lília, Catavento, A Chamada, Tema dos deuses e From the lonely afternons permanecem sem letra. Talvez o exemplo mais marcante de sua vocação para a música instrumental seja sua decisão de lançar o disco Milagre dos peixes (1973) quase todo instrumental, depois que a censura do governo militar "... cortou praticamente na íntegra as letras da música Cadê, Os Escravos de Jó e Hoje e dia de El Rey... " (FILHO, 2012, p.7), canções consideradas subversivas na época.

\section{2 - Histórias de Novena}

Para compreender 0 estilo emergente de Milton Nascimento e Márcio Borges, o presente estudo apresenta uma análise formal, motívica, harmônica e da relação texto-música da canção Novena. Um estudo detalhado das duas outras canções dessa dupla que também marcaram o início composicional do Clube da Esquina - Crença e Gira girou - também mereceram análises detalhadas 

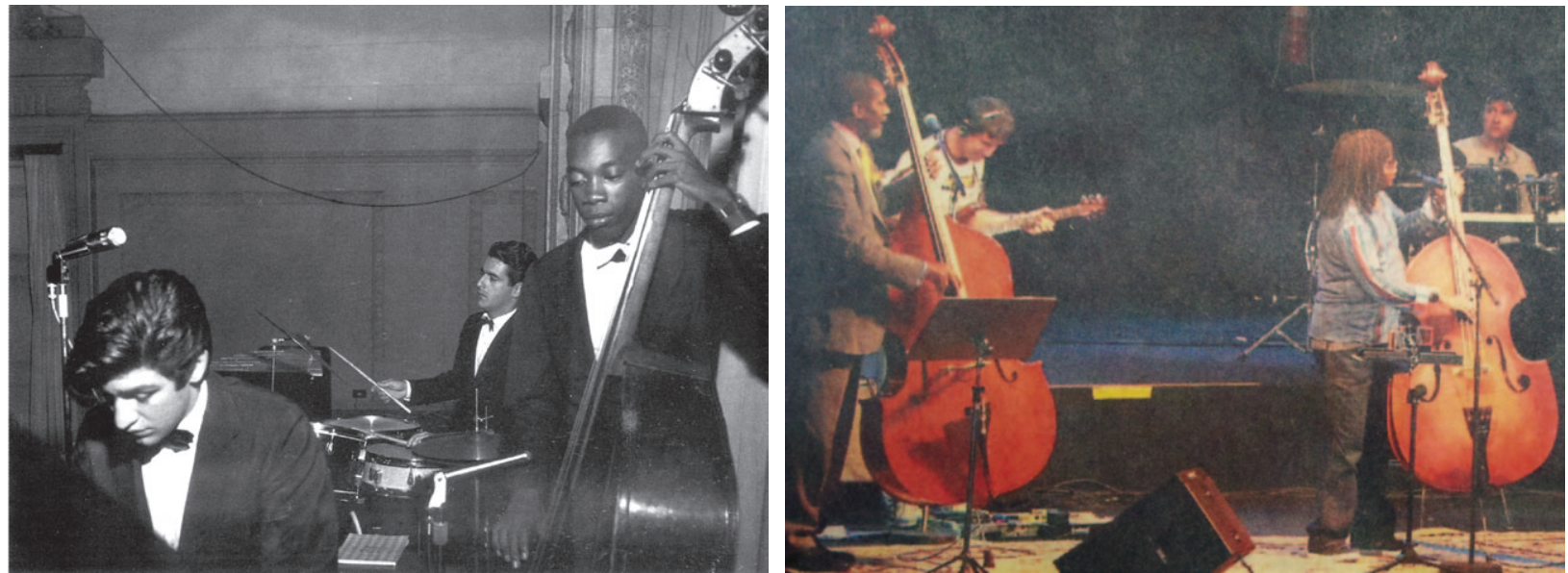

Ex.3a, b - Milton Nascimento e a música instrumental (traço do Clube da Esquina) em dois momentos com o contrabaixo: com o Trio Berimbau (foto com Wagner Tiso ao piano e Paulinho Braga na bateria, em 1964; BORGES, 1996, p.363) e com o jazzista norte-americano Ron Carter (contrabaixo), Wilson Lopes (guitarra) e Lincoln Cheib (bateria) no Festival "Tudo é Jazz" de Ouro Preto em 2008 (ESTADO DE MINAS, 2008).

pelo segundo co-autor do presente artigo (LOPES, 2010), mas devido à sua extensão, fogem ao escopo do presente artigo. Ao lado de Novena, as canções Crença e Gira girou também revelam características específicas da dupla que podem ser associadas à variedade de influências musicais e hibridismo que mais tarde se consolida como um dos traços estilísticos do Clube da Esquina (a música religiosa da tradição católica, a música da herança africana no Brasil, o folclore, a canção popular brasileira vocal, o rock, o jazz, a música instrumental experimental, a música erudita, entre outros). Juntas, essas três canções também podem ser vistas como um tríptico inspirado pelo filme Jules e Jim de François Truffaut e seus três personagens. Um tríptico com três canções contrastantes, mas ao qual podemos associar os personagens envolvidos naquele momento histórico.

Novena foi a primeira das três canções a ficar pronta na noite que marca o início composicional do Clube da Esquina. Dedilhando o violão, Milton Nascimento ainda estava imerso na atmosfera do filme que acabaram de assistir: "A única coisa que me lembro é a imagem dos dois, Jules e Jim, na beira do rio Sena e ela Catherine, vindo em uma bicicleta. É isso... era o que vinha na minha cabeça" (NASCIMENTO, 2009). Enquanto ele esboçava os acordes e a melodia, Márcio escrevia a letra da música que chamaria inicialmente de Paz do Amor que Vem. Mais tarde, a letra Ihe soou ingênua:

\footnotetext{
A vida vem de algum lugar

Para nos falar de alguma paz

De um amor...
}

Então, preferiu escrever outra letra e mudou o título para Novena, referindo-se às novenas de Natal de sua família, mas com um viés mais político, falando sobre os pobres, os socialmente excluídos, "... como se fosse uma Novena profana, uma Novena não religiosa. Seria a Novena do marginal, e não aquela Novena classe média da família burguesa" (BORGES, 2010):
Se digo um ai, é por ninguém

É pela certeza de saber que tudo tem

Tem sua vez de lá retornar

Ao lugar mais fundo, fundo, fundo, mais que o mar

Se digo sol, não tem talvez

Não espero mais a chuva

Só preparo o meu começo

A explosão de toda luz

A chama, chama, chama, chama

Se digo amor, só é por alguém

É pelos malditos deserdados desse chão.

Apesar de Milton dizer que "... mais tarde, eu quero ver se faço uma gravação com as duas letras [de Novena]... " (BORGES e NASCIMENTO, 2012c, Epilogo), a fala de Márcio Borges na segunda epígrafe no início do presente artigo - "... o Bituca é o Sol e eu sou a Lua... (Márcio BORGES, 2012) - reflete o cuidado do letrista em adequar o conteúdo da letra à atmosfera musical da canção. Em outras palavras, a letra não precedeu a música e harmonia que vieram antes e, assim, faz mais sentido pensar na relação entre texto e música como Márcio sugere, as palavras gravitando ao redor dos sons.

À letra de Novena, em favor dos desfavorecidos ("Se digo um ai... é pelos malditos deserdados desse chão"), podemos associar o caráter rebelde, combativo e engajado de Márcio Borges. ${ }^{4} \dot{A}$ letra de Crença, que fala da luta diária ("Eu sei que venho lutando, com esta vida de desvalença, eu sei que luto sozinho... ") podemos associar o desafio pelo qual passava Milton Nascimento ao se mudar do interior para Belo Horizonte. A letra de Gira girou, a última do tríptico, fala do amor e da esperança ("Desperta minha amada, linda como a terra, e vem pelos campos, com mil vivas ao redor... eu vou achar a alegria... ") à qual podemos associar a bela, misteriosa e transgressora personagem de Jeanne Moreau (Ex.4a,b; ela se veste de homem, põe bigode postiço, fuma, vence os homens em 
disparada pelas ruas, triangula com os dois... ), que foi a musa dos dois amigos no filme e na plateia. Fazemos aqui um paralelo ao triângulo amoroso do filme e o "triângulo amoroso" entre Bituca, Márcio Borges e outra musa: a música, chamada por eles de "nossas filhas" e que também, como veremos em Novena, não é nada convencional para uma dupla que inicia sua carreira de compositores.

A primeira gravação de Novena só ocorreu 14 anos depois de sua composição, no disco Amor de Índio, o segundo da carreira do cantor e compositor mineiro Beto Guedes, também membro do Clube da Esquina. Por mero esquecimento, Milton, que até o final de 2013 havia escrito 320 músicas e lançado 36 discos autorais, gravou Novena uma única vez, no disco Angelus (NASCIMENTO e BORGES, 1993), somente 29 anos após sua concepção! Nessa gravação realizada em Nova lorque, ele contou com lendários músicos de jazz: Herbie Hancock (piano), Pat Metheny (guitarra), Jack Dejohnette (bateria), Ron Carter (contrabaixo) e Naná Vasconcelos (percussão). Milton Nascimento, que toca violão nessa faixa, utiliza sua voz não apenas para cantar a letra mas também realiza diversas vocalizações, recorrendo ao processo de dubbing (regravação), que ele costuma chamar de "os primos" (ele cantando com ele mesmo).

Há duas versões contadas por ele sobre os desacertos dessa gravação que deveria ser feita em estúdio, mas sem cortes, como se fosse ao vivo. Em entrevista ao segundo co-autor do presente artigo, Milton NASCIMENTO (1993) contou que respondeu, brincando, a uma pergunta de Pat Metheny de que o groove seria de rock mas que "... o lance é livre, toquem como sentirem" ao que Jack DeJohnette se levantou da bateria e bateu palmas, prevendo um momento de liberdade criativa que bateristas costumam não usufruir em baladas. Em vão. Ao caos que se seguiu, Milton retomou as rédeas para voltar ao clima de súplica e protesto de Novena.

Na segunda versão, Milton contou para Márcio Borges (BORGES e NASCIMENTO, 2012c, Epílogo) que
"Então, eu estava no estúdio, estavam o Pat Metheny [guitarra] o Herbie Hanckock [piano], o Jack DeJohnette [bateria] e Naná Vasconcelos [percussão] [além de Ron Carter no contrabaixo]. Então, eu falei pro Pat, na hora que a gente estava escrevendo as cifras... que essa tinha sido realmente a minha primeira música... teve uma hora que eu dei um acorde no meio que todo mundo parou. Parou, assim, eu olhando, foi uma coisa incrivel, que eu vi que tinha derrubado os meus ídolos. (risos) 0 acorde que estava dando era aquele, mas eles tinham que seguir naqueles que eles já estavam dando mesmo. Ai tivemos que fazer a gravação de novo, e aí aconteceu uma outra coisa engraçada, porque eu faço uma coisa no violão e depois, da outra vez, o Herbie Hanckock pensou que eu ia repetir o negócio, e eu não repito, então ele deu o acorde e... [Márcio Borges] Caiu! ... [Bituca] É. (risos).

A valorização da música instrumental por Milton fica evidente nessa gravação: a canção dura três choruses incompletos (em função do fade out no seu final), sendo que quase todo o segundo chorus (exceto pela última estrofe) e o terceiro são dedicados à improvisação instrumental (com solos de piano e guitarra).

A análise de Novena aqui apresentada é baseada na lead sheet publicada às p.40-42 deste volume de Per Musi, que foi preparada a partir da transcrição do primeiro chorus dessa gravação de Milton Nascimento no disco Angelus. A transcrição foi realizada pelo segundo coautor do presente artigo, com a autorização e estímulo dos compositores. ${ }^{5}$

\section{3- Análise de Novena: harmonia, forma, motivos e relação texto-música}

Milton é notável por suas passagens imperceptíveis entre o falsete e a voz de peito. ${ }^{6}$ Em Novena, ele geralmente dobra sua voz na oitava superior e em outros intervalos. Mas quando canta com uma voz apenas no registro agudo, escolhe o falsete como timbre predominante. Mais do que isso, ao invés de usar sua técnica impecável para descer do falsete para a voz de peito, ele escolhe a ruptura entre esses dois timbres como forma de enfatizar o final de cada verso e, por conseguinte, deixar mais angustiante e tenso o final de cada seção formal da canção (Ex.5).
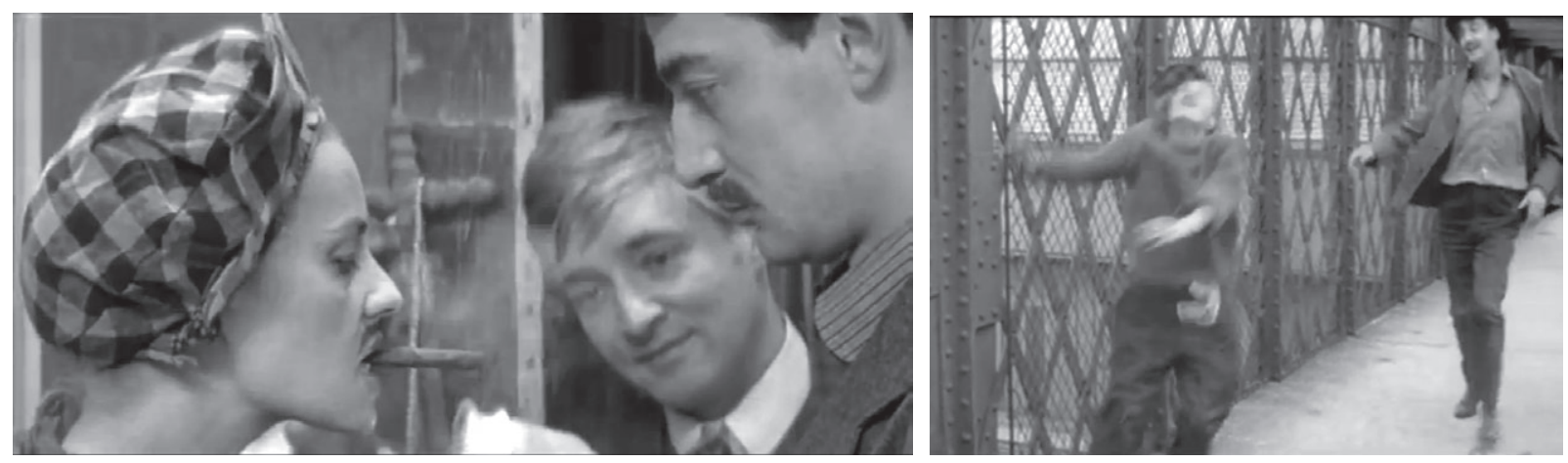

Ex.4a, b - Jeanne Moreau no filme Jules et Jim de François TRUFFAUT (1962), bela, misteriosa e transgressora, inspiração para a canção Novena, música bela, misteriosa e transgressora que marcou o início da carreira de Milton Nascimento e Márcio Borges. 
Milton Nascimento acomodou os versos que Márcio Borges escreveu para Novena dentro da métrica do compasso composto $6 / 8$, seguindo uma das fórmulas mais comuns no jazz: a forma $A$ A $B \quad A$, com cada seção obedecendo à quadratura clássica (mesmo número de compassos, em múltiplos de quatro). Já atento à questão do arranjo, no qual valoriza a música instrumental - cria um chorus de improvisação e inclui sua voz apenas vocalizada, sem letra. Ainda em relação ao arranjo, ele prepara a canção com uma Introdução e a finaliza com uma Coda. Um esquema formal simplificado das seções da canção (Ex.6, contendo apenas um dos três choruses da gravação) também mostra que variedade é uma caracteristica de seu estilo: a recapitulação da seção $A$ é sempre variada (como $A^{\prime}$ e $A^{\prime \prime}$ ). Sua tendência à variedade também aparece na estrutura interna das seções, pois Milton já se sentia livre o suficiente para não seguir fielmente a simetria da quadratura de 64 compassos (distribuídos como $16+16+16+16$ compassos entre as seções), mas sim chegar a uma solução de quadratura menos óbvia (64 compassos, distribuídos como $16+16+18+14$ ).

0 centro modal de Ré Dórico em Novena é estabelecido claramente na Introdução. Além do acorde de $\mathrm{Dm} 7$ ser o ponto de partida e chegada, e o fato do acorde suspenso A7/4 não resolver em um acorde dominante, os três únicos acordes utilizados nessa seção - Dm7, A7/4 e
Am7 -, contém todas as notas diatônicas desse modo. As demais seções formais são organizadas harmonicamente em torno do modo de Ré Dórico, progredindo à sua relativa maior (Fá Maior), à sua subdominante menor (Sol Menor), e depois passa por Fá Dórico (homônimo menor da relativa maior) antes de retornar ao modo de Ré Dórico (Ex.6).

0 modo Dórico de Ré é afirmado logo na Introdução (c.116), em que encontramos os acordes $D m 7$ e sua dominante menor Am7, revelando uma cadência modal caracteristica da linguagem de Milton Nascimento. ${ }^{7}$ Essa característica modal é reforçada na Seção $\boldsymbol{A}$ (c.17-32), onde se inicia o canto, com uso sucessivo de acordes de empréstimos modais. A Seção $A^{\prime}$ (c.33-48) se diferencia da Seção $A$ por uma mudança do ritmo da melodia (c.38-39) e uma resolução de engano no final da seção, $\mathrm{Bm} 7$ ao invés de Dm7 (c.46-47). Na Seção B (c.49-66), que tem Sol menor como modo central, destaca-se a ambiguidade tonal nos c.57-58, provocada pela nota Si bemol da melodia em meio ao acorde Sol maior (com seu Si natural). Na Seção $A^{\prime \prime}$ (c.67-80), Milton Nascimento utiliza extensivamente o procedimento de re-harmonização, trocando a maioria dos acordes maiores usados na Seção $A$ (que se repetem na Seção A) por acordes menores sem dissonâncias (c.6776). Essa mudança tão radical e o consistente padrão de acordes paralelos sugerem que sua inspiração pode estar

\begin{tabular}{|c|l|l|}
\hline Seção & Falsete & Voz de peito \\
\hline $\boldsymbol{A}$ & (c.17-30) "Se digo um ai... saber que tudo & (c.31) tem" \\
\hline $\boldsymbol{A}^{\prime}$ & (c.33-45) "Tem sua vez... fundo, fundo & (c.46) mais que o mar" \\
\hline $\boldsymbol{B}$ & (c.49-63) "Se digo sol... de toda luz, & (c.64) a chama, chama, chama, chama" \\
\hline $\boldsymbol{A}^{\prime \prime}$ & (c.67-76) "Se digo amor... é pelos & (c.76) malditos, deserdados desse chão" \\
\hline
\end{tabular}

Ex.5 - Relação entre tipos de voz (falsete e voz de peito) e prosódia na letra de Novena de Milton Nascimento e Márcio Borges.

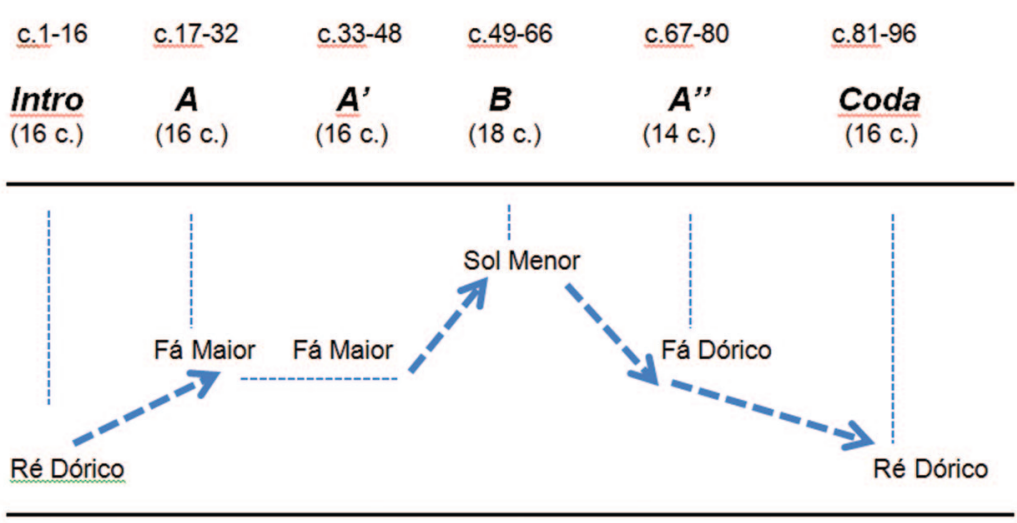

Ex.6 - Esquema formal e harmônico de Novena de Milton Nascimento e Márcio Borges (veja lead sheet completa com indicação das Seções às p.40-42 deste número de Per Musi). 
na utilização idiomática das formas de mão esquerda se movimentando ao longo do braço do violão (Ex.7).

Outra característica do estilo do jovem Milton Nascimento, e que se tornou marcante em diversas outras canções, é a repetição de estruturas harmônicas idênticas ou semelhantes cujas fundamentais estão a uma distância de terça menor. Em Novena, ele utiliza este artifício para harmonizar a terceira nota da melodia cantada: o Lá bemol (c.19) e, assim, progride do acorde de Fá Maior para o acorde de Lá bemol Maior com Ré no baixo (Ex.8a). Passagens semelhantes podem ser encontradas no seu repertório posterior (Ex.8b, c, d, e), como Morro Velho (1967) de sua autoria apenas; Vera Cruz (1969) e Viola Violar (1974) de Milton Nascimento e Márcio Borges; e Cais (1972) de Milton Nascimento e Ronaldo Bastos.

Além desse jogo entre os modos Maior e Menor observado amplamente na re-harmonização da Seção A", Novena já traz, em diversas instâncias, a ambiguidade tonalmodal (mode mixture) como um dos procedimentos que também caracteriza o estilo de Milton Nascimento desde a inauguração de sua carreira como compositor. Logo no início da parte cantada (Seção $A, c .17)$, a terceira nota esperada seria um Lá natural: seja como a terça maior do acorde de Fá Maior do início dessa parte cantada ou como a quinta do acorde de Ré menor que predomina em toda a Introdução. Entretanto, essa nota aparece como um Lá bemol (c.19), ou seja, a terça menor de Fá menor. De forma semelhante, a ambiguidade entre as terças maior e menor nos surpreende de forma inversa mais tarde na canção, pois após o acorde de Fá Menor no início da Seção $A$ " (c.67), ao invés da nota esperada Lá bemol, Milton escolhe um Lá natural (c.68). Diferentemente do final a Seção $A$ em Ré Menor, o final da Seção $A^{\prime}$ traz dois novos acordes, Bm7 e G/B (c.47-48), tomados por empréstimo modal do tom de Ré Maior. A ambiguidade harmônica é ainda explorada por Milton na Seção $\boldsymbol{B}$, quando, no trecho mais agudo da canção, ele canta um Si bemol sobre um acorde de Sol Maior com Si natural no baixo (c.57) gerando um acorde maior-menor. Aqui essa ambiguidade entre os modos Maior e Menor faz uma referência à utilização da blue note, procedimento bem característico em vários estilos do jazz. A Coda é uma repetição da introdução, mas com uma diferença de instrumentação, em que a melodia do violão é dobrada pela voz (c.81-96), acréscimo que dá maior continuidade à linha melódica e traz o timbre característico do falsete de Milton nascimento. Podemos aqui sugerir uma relação do estilo incipiente de Milton com as sutilezas da linguagem do movimento cinematográfico Nouvelle Vague, em que as diversas mudanças são sutis, em que as repetições nunca são literais, em que elementos contraditórios são justapostos.

Diversos trechos mostram o gosto de Milton pelo empréstimo modal. Na Seção $A_{1}$ que é construída basicamente com progressões sobre o pedal de tônica Ré, o acorde de Ab (c.19) aparece como um empréstimo modal dissonante, que pode ser explicado como o quinto grau do modo Ré Lócrio. Mais para o final da Seção $A$, existe uma ênfase em acordes maiores com a fundamental Mi e tensões crescentes. Primeiro, os acordes E13 e E13(b9) nos c.27-28, que podem ser analisados como empréstimos modais do segundo grau maior de Ré Diminuto. Em seguida, há o acorde $\mathrm{E}(69)$ b13) no c.29, que pode ser visto como uma dominante do modo Lá Menor Harmônico. Já no início da Seção $B$, logo após o acorde da tônica Sol Menor, aparece o acorde de Eb7/13, emprestado do modo Sol Lócrio. Outro recurso harmônico utilizado por Milton é a aproximação cromática, no c.55, onde o acorde Abm7 está a um semitom dos acordes $\mathrm{Gm} 7$ (c.53) e G (c.57).

Além de um esquema harmônico bem estruturado, outro elemento composicional que dá unidade a Novena é a recorrência de materiais temáticos contrastantes, que aparecem na Introdução ou na Seção A e que organizam todas as seções seguintes da canção. Aqui denominamos esses materiais temáticos como motivos $M 1, M 2, M 3$ e $M 4$ (Ex.9). 0 primeiro motivo - $M 1$ - que aparece no início da Introdução (c.1-3; Ex.9), se caracteriza por uma insistente horizontalidade e estaticidade que resulta da insistente repetição da nota Fá em semínimas pontuadas; repetição

\begin{tabular}{|c|c|c|c|c|c|c|}
\hline \multirow{4}{*}{ Seção A } & c.17 & $F / D-G / D$ & G/D & $A b / D$ & $\| A b / D-G / D-F / D$ & $\|$ \\
\hline & c. 21 & $F / D-G / D$ & G/D & $A b / D$ & $A b / D$ & $\|$ \\
\hline & c. 25 & $A b / D-G / D$ & $G b / D-F / D$ & $\| E^{13} / D-E^{13(69)} / D$ & $E^{13} / D-E^{13(69)} / D$ & 11 \\
\hline & c.29 & $E^{13} / D-E^{13(69)} / D$ & $A^{7 / 4}-A b^{13}$ & $\| D m^{7}-G / D$ & G/D & || \\
\hline \multirow{4}{*}{ Seção $A^{\prime \prime}$} & c.67 & $\mathrm{Fm} / \mathrm{D}-\mathrm{Gm} / \mathrm{D}$ & $\mathrm{Gm} / \mathrm{D}$ & $\mathrm{Am} / \mathrm{D}$ & $\| \mathrm{Am} / \mathrm{D} \mathrm{Abm} / \mathrm{D} \mathrm{Gm} / \mathrm{D}$ & || \\
\hline & c.71 & $\mathrm{Fm} / \mathrm{D}-\mathrm{Gm} / \mathrm{D}$ & $\mathrm{Gm} / \mathrm{D}$ & $\| \mathrm{Gm} / \mathrm{D}-\mathrm{Am} / \mathrm{D}$ & $\mathrm{Am} / \mathrm{D}$ & $\|$ \\
\hline & c.75 & $A b m / D-G m / D$ & $\mathrm{Gbm} / \mathrm{D}-\mathrm{Fm} / \mathrm{D}$ & $\| E 13 / D-E 13(b 9) / D$ & & \\
\hline & c.78 & $|E 13 / D-E 13(b 9) / D| \mid$ & $A 7 / 4-A 7$ & Dm7 & |l & \\
\hline
\end{tabular}

Ex.7 - Quadro com re-harmonização da Seção $A$ (c.17-32) de Novena, em que a maioria dos acordes maiores são trocados por acordes menores na Seção $A^{\prime \prime}$ (c.67-80). 

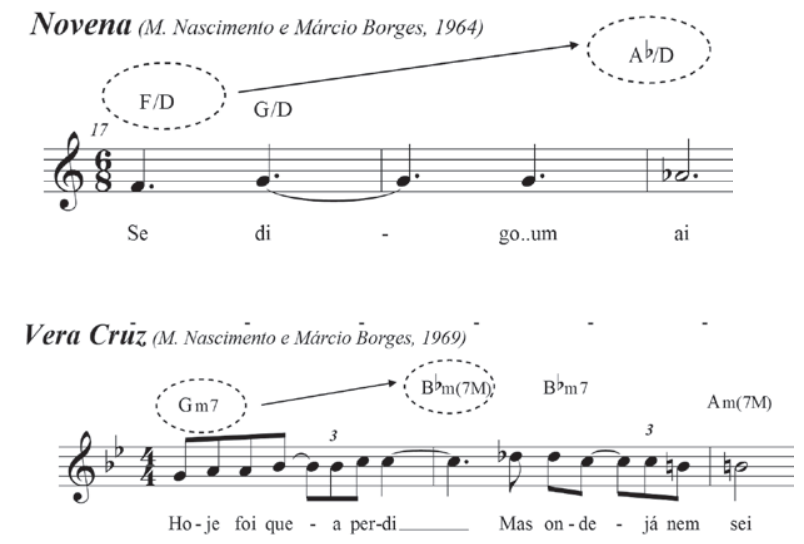
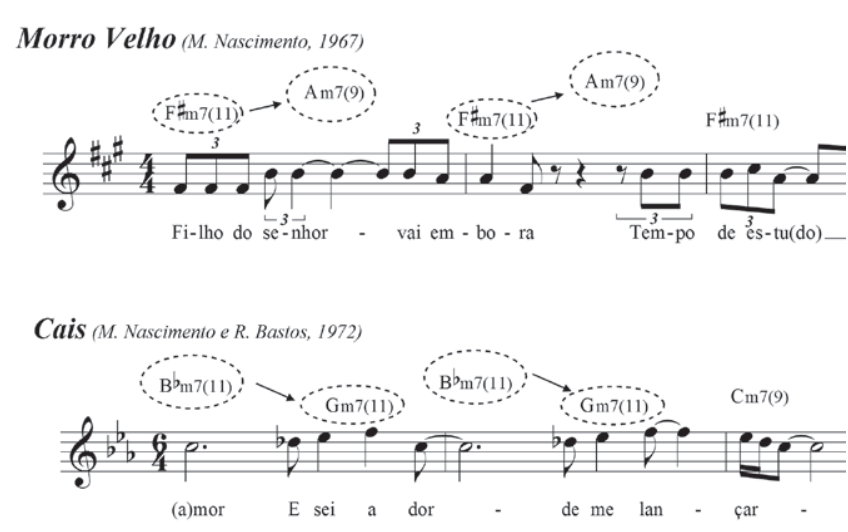

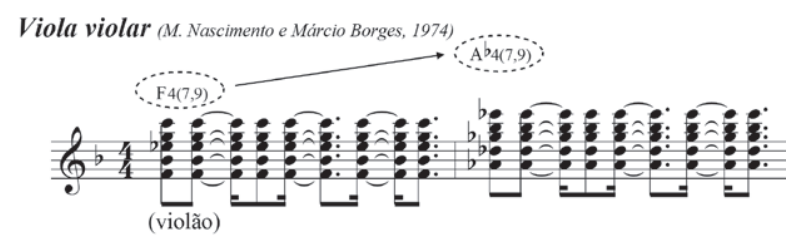

Ex.8a, b, c, d, e - Progressão de acordes com fundamentais distanciadas de uma terça menor em Novena de Milton Nascimento e Márcio Borges e em obras posteriores.

que logo reaparece transposta (c.5-7). 0 segundo motivo - M2 - que também aparece na Introdução (c.5 e depois com transposição no c.8; Ex.9), apresenta um movimento melódico descendente em graus conjuntos diatônicos que reflete uma resolução harmônica, progredindo da nota Sol (sub-dominante) para a nota Ré (tônica). Assim, temos na Introdução, duas sensações que se opõem: a horizontalidade de $\boldsymbol{M} 1$ e o movimento descendente de $\boldsymbol{M} \mathbf{2}$.

0 terceiro motivo - M3 - aparece na Seção A (c.17-24; Ex.9), onde se inicia o canto, caracterizando-se por um movimento ascendente por graus conjuntos, a partir da tônica Fá. 0 quarto motivo - $\mathbf{M} 4$ - que também aparece na Seção $A$ (c.25-26; Ex.9), que se opõe a $M 3$, caracteriza-se por um movimento descendente cromático em cada tempo do compasso (semínimas pontuadas) graus conjuntos. Assim, os motivos de Novena sintetizam materiais temáticos contrastantes: descendente, horizontal e ascendente. A predominância do movimento descendente (motivos M2 e M4) e harmonias menores ou dissonantes contribuem para o clima geral de angústia ("Se digo um ai... " no c.17) e revolta ("... É pelos os malditos deserdados deste chão... " no c.75) da canção, dentro da qual, esporadicamente, há um fio de esperança ("... Se digo amor... " no c.67).

A grande unidade temática de Novena é assegurada pela recorrência dos quatro motivos, que reaparecem em suas formas originais ou por meio do recurso de transposição para outros graus da escala e/ou para oitavas superiores: $M 1$ no c. 1 , c.5 e c. $43-45 ; M 2$ no c. 5 e c. $8 ; M 3$ no c. 17 e c. 49 ; e $M 4$ no c. 25 , c.46-47 e c.70.
Muitas vezes as modificações dos motivos de Novena implicam em alterações resultantes de acréscimos ou retiradas de notas, mudanças de intervalos ou de ritmo ou, mesmo, re-harmonizações de seus acompanhamentos. 0 motivo $M 1$, que incialmente é apenas instrumental e enfatiza a nota Fá na Introdução (c.1), reaparece na Seção $A$ (c.27-30; Ex.10a) com letra no grave oscilando entre as notas Mi e Fá e com alteração rítmica (c.28-29). Em seguida, essa oscilação (que ainda mantém a horizontalidade de M1) aparece com simples semínimas na Seção $A^{\prime}$ (c.43-45; Ex.10b). Na Seção $B$ (c.63-66; Ex.10c), já na oitava superior, a oscilação se inverte - desta vez Fá - Mi. A relação textomúsica é bem evidente aqui: a insistência melódica nessas notas é combinada com a repetição de palavras: primeiro no registro grave (e mais escuro) que realça o "... retornar ao lugar lugar mais fundo, fundo, fundo ... " (c.43-45) e, depois, no registro agudo (e mais brilhante) que realça "A explosão de toda luz" na redundância de "A chama, chama, chama, chama ..." (c.63-66).

As transformações em M2 são comuns. No c.20 da Seção $A$, esse motivo é fragmentado e apenas uma parte dele aparece (Ex.11a). Nos c.30-31, ainda na Seção $A$, a antecipação (o Ré, como nos c.4-5) é substituída por uma escapada (o Fá-Ré nos c.30-31; Ex.11b). Já na Seção $B$ (Ex.11c), sua descendente, que percorre uma terça maior (Lá-Sol-Fá) no c.61, é comprimida a uma terça menor (Láb-Sol-Fá) no compasso seguinte, refletindo também na harmonia que, para acomodar esta inflexão, passa de F/a para Abm6. 

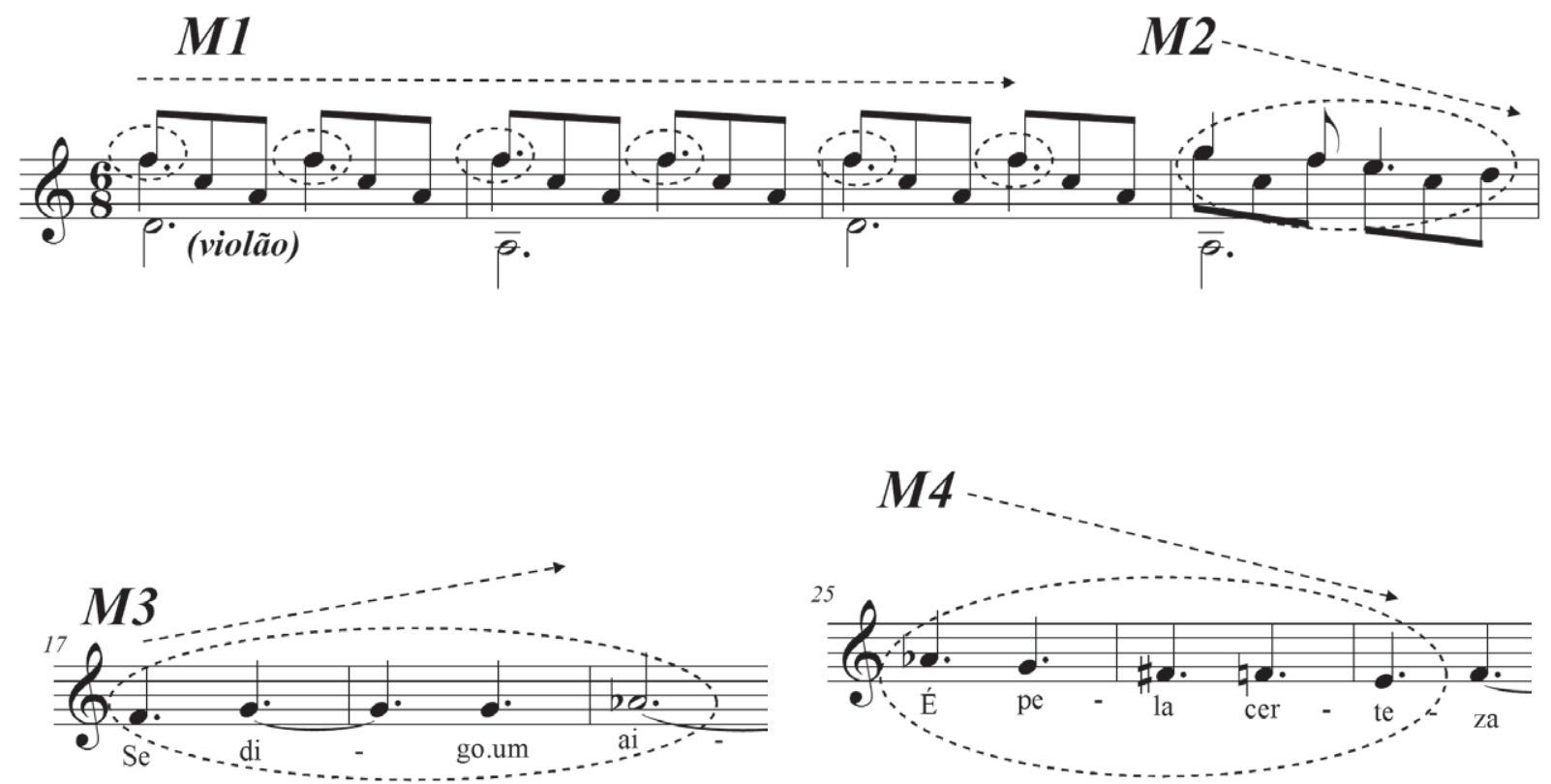

Ex.9 - Motivos M1, M2, M3 e M4 com seus contornos melódicos, estruturadores de todas as seções de Novena de Milton Nascimento e Márcio Borges.
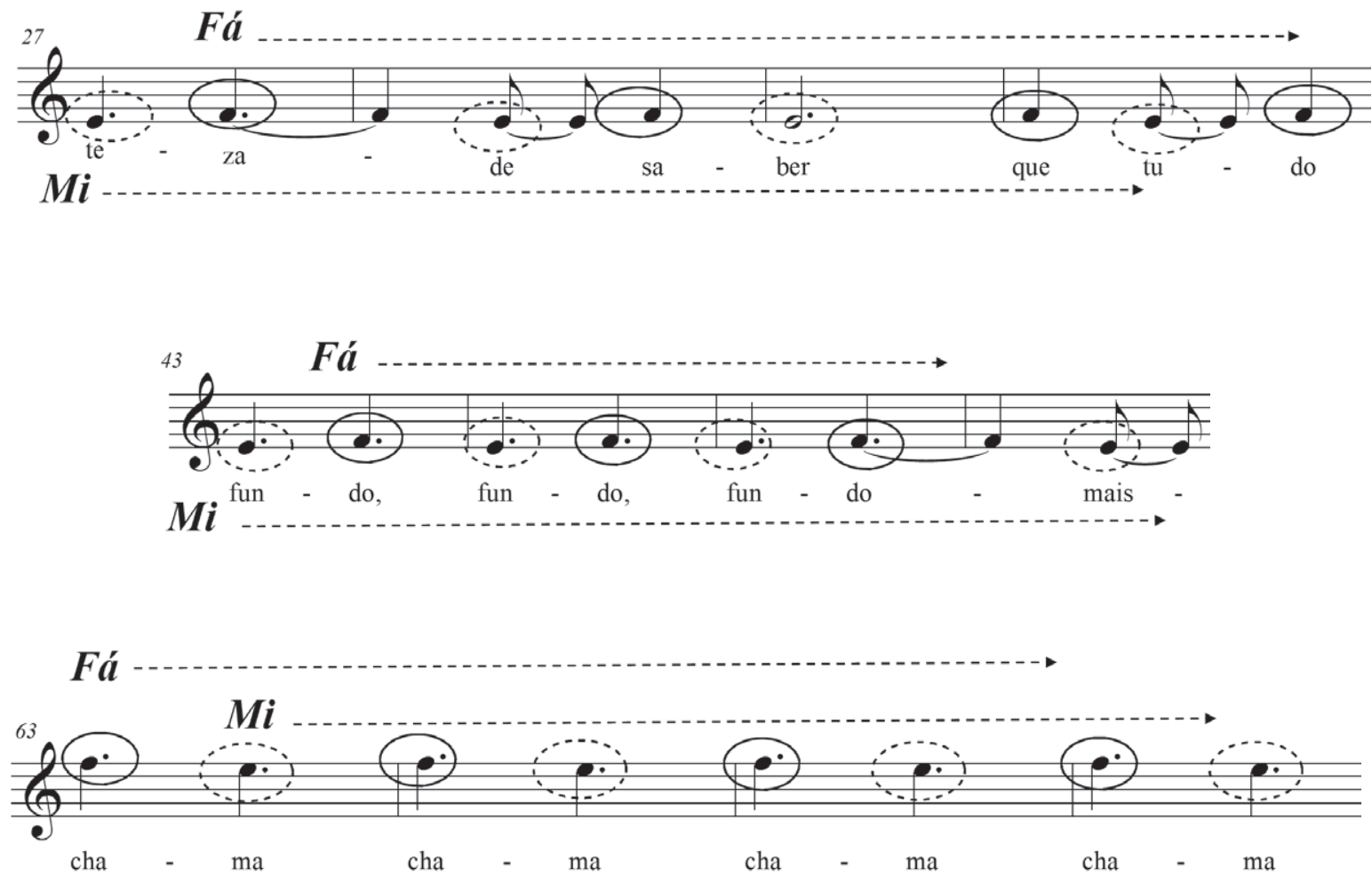

Ex.10a, b, c - Modificações do motivo básico M1 e relação texto-música em Novena de Milton Nascimento e Márcio Borges. 

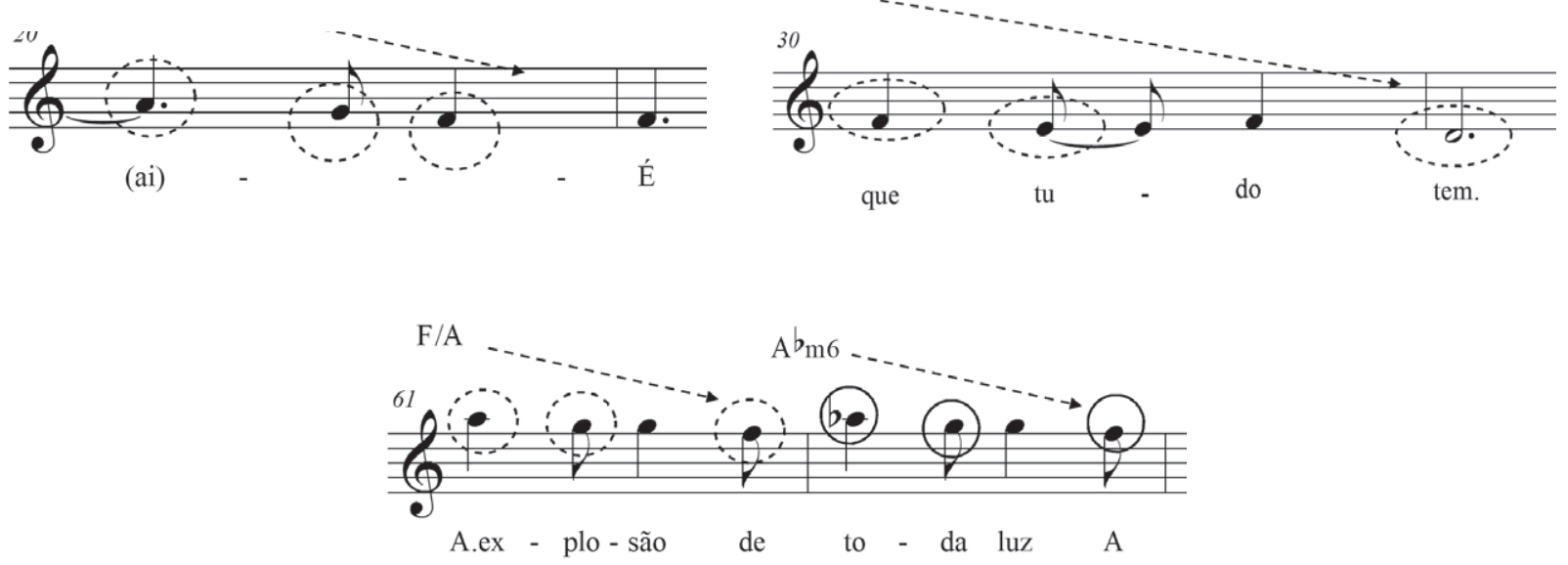

Ex.11a, b, c - Transformações no motivo M2 em Novena de Milton Nascimento e Márcio Borges: fragmentação, alteração de intervalo e compressão de intervalo.
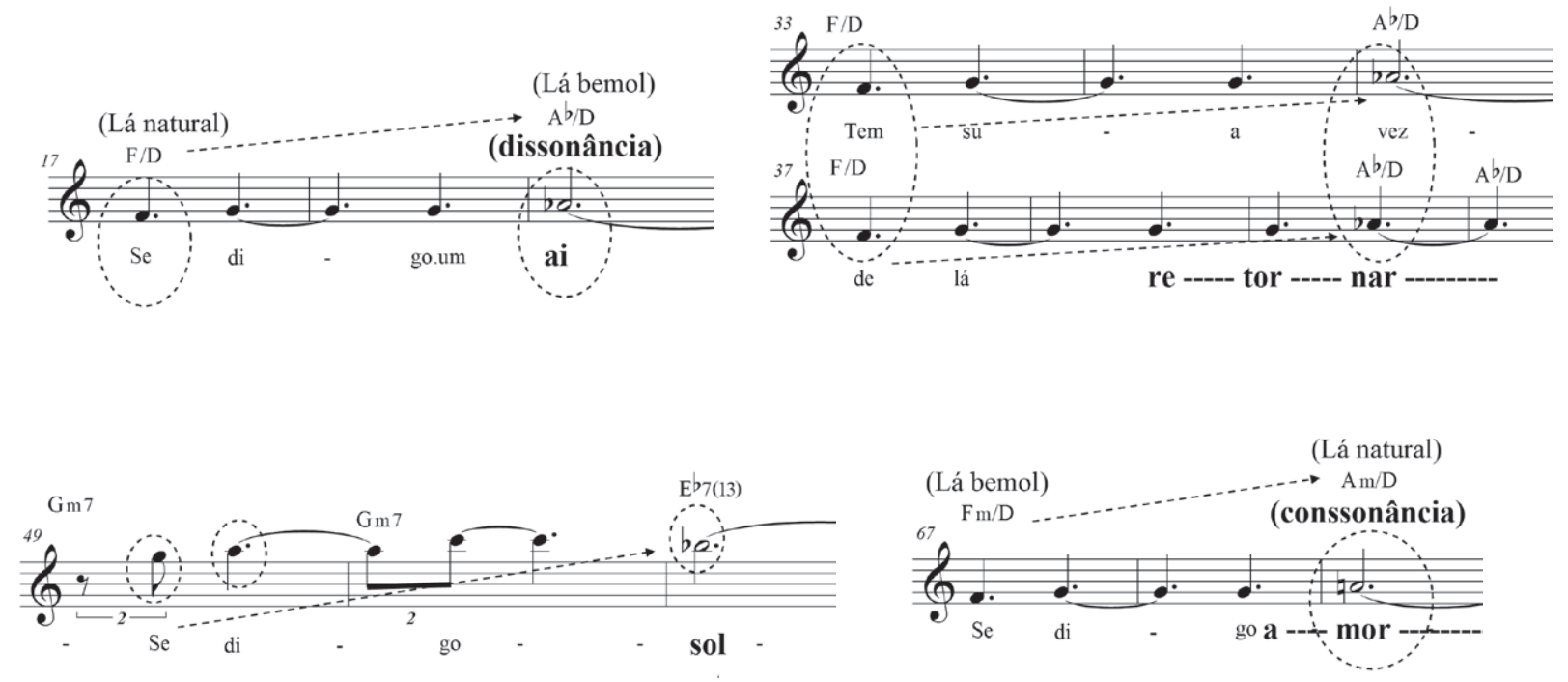

Ex.12a, b c c d - Relações texto-música com a nota Lá do motivo M3 de Novena de Milton Nascimento e Márcio Borges: sugestões de dor (dissonância), retorno (repetição), brilho (oitavação) e amenização (alteração intervalar e re-harmonização).

A nota mais aguda da ascendente que caracteriza $M 3$ serve à relação texto-musica por diversas vezes. Primeiro, 0 pungente e dissonante Lá bemol da Seção A(c.19), atingido no campo harmônico de Fá maior e harmonizado com um $A b / D$, aumenta a dramaticidade da onomatopeia de dor no verso "Se digo um ai ... " (Ex.12a). Depois, nos c.33-40 da Seção $A$ ', quando a melodia retorna ao Lá bemol pela segunda vez, o verso diz "... de lá retornar... " (Ex.12b). Depois, quando este mesmo Lá bemol é cantado uma oitava acima na Seção $B$ (c.51) e se encaixa como a terça do acorde re-harmonizado de $E b 7(13)$, sua luminosidade sublinha 0 verso que diz "Se digo sol..." (Ex.12c). Finalmente, quando a letra se torna otimista nos c.67-74 da Seção A", com "Se digo amor, só é por alguém ... ", o Lá bemol se torna Lá bequadro e a harmonia é amenizada, com o Lá tornandose fundamental do acorde consonante de Am/D (Ex.12d).
0 motivo cromático $M 4$ é alterado por fragmentação, tornando-se mais curto nos c.46-47 (Ex.13a) e no c.70 (Ex.x13b).

Outro procedimento que ocorre em Novena é a imbricação de motivos. Por exemplo, as características marcantes dos motivos $\mathbf{M} 2$ (a linha descendente) e $M 1$ (a estaticidade horizontal) são combinadas nos c.57-59, trecho no qual Miton ainda utiliza um deslocamento rítmico e re-harmonização do acorde de $\mathrm{G} / \mathrm{B}$ para Bbm6 (Ex.14).

A tabela do Ex.15 resume as recorrências dos motivos M1, M2, M3 e M4 e suas transformações ao longo das seções de Novena. 

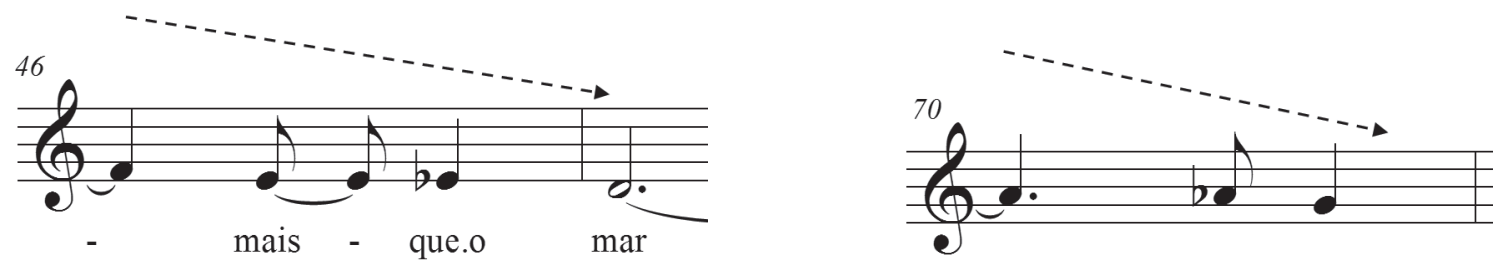

Ex.13a, b - Fragmentações do motivo cromático M4 de Novena de Milton Nascimento e Márcio Borges.

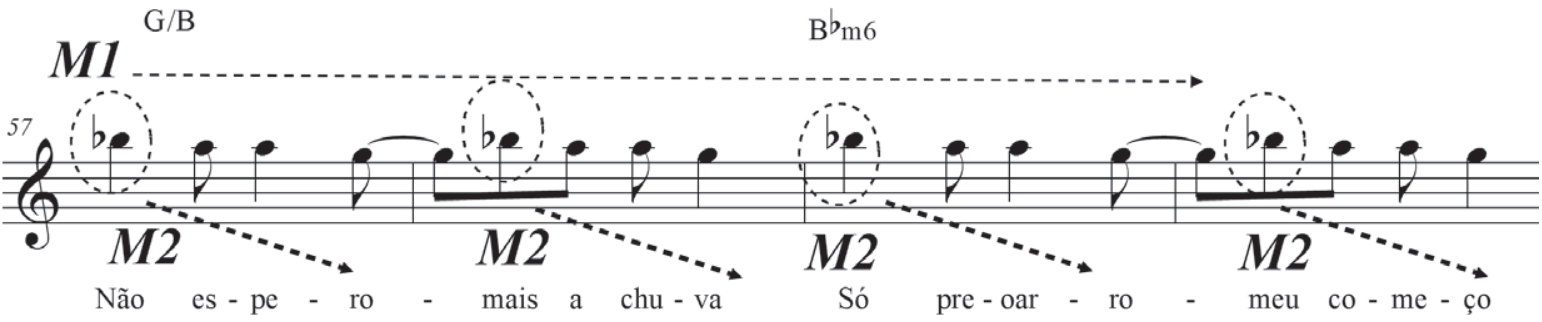

Ex.14 - Imbricação dos motivos básicos M2 e $M 1$ com deslocamento rítmico e re-harmonização em Novena de Milton Nascimento e Márcio Borges.

\begin{tabular}{|c|c|c|c|c|c|c|}
\hline & Intro & $A$ & $A^{\prime}$ & $B$ & $A^{\prime \prime}$ & Coda \\
\hline M1- original & $\begin{array}{l}\text { c. } 1-3 \\
\text { c. } 9-11\end{array}$ & & & & & $\begin{array}{l}\text { c.81-83 } \\
\text { c.89-91 }\end{array}$ \\
\hline M1- modificado & $\begin{array}{c}\text { c.5-7 } \\
\text { c. } 13-15\end{array}$ & c. $27-29$ & c. $43-45$ & $\begin{array}{l}\text { c. } 57-60 \\
\text { c. } 63-66\end{array}$ & c. $77-80$ & $\begin{array}{l}\text { c. } 85-88 \\
\text { c.93-95 }\end{array}$ \\
\hline M2- original & $\begin{array}{l}\text { c. } 4 \\
\text { c. } 12\end{array}$ & & & & & $\begin{array}{l}\text { c. } 84 \\
\text { c. } 92\end{array}$ \\
\hline M2- modificado & $\begin{array}{l}\text { c. } 8 \\
\text { c. } 16\end{array}$ & $\begin{array}{c}\text { c. } 20 \\
\text { c. } 30-31\end{array}$ & c.36 & c. $57-62$ & c.80-81 & $\begin{array}{l}\text { c. } 88 \\
\text { c. } 96\end{array}$ \\
\hline
\end{tabular}

\begin{tabular}{|l|l|l|l|l|l|l|}
\hline M3- original & & $\begin{array}{l}\text { c.17-20 } \\
\text { c.21-24 }\end{array}$ & c.33-36 & & & \\
\hline M3- modificado & & & c.37-40 & $\begin{array}{r}\text { c.49-52 } \\
\text { c.53-56 }\end{array}$ & $\begin{array}{r}\text { c.67-70 } \\
\text { c.71-74 }\end{array}$ & \\
\hline
\end{tabular}

\begin{tabular}{|l|l|l|l|l|l|l|}
\hline M4- original & & c.25-27 & c.41-43 & & c.75-77 & \\
\hline M4- modificado & & & c.46-47 & & c.70 & \\
\hline
\end{tabular}

Ex.15 - Tabela com recorrência dos motivos $M$ 1, $M 2, M 3$ e $\mathbf{M 4}$ originais e suas modificações ao longo das seções de Novena de Milton Nascimento e Márcio Borges. 


\section{4- Conclusões}

A análise de Novena, apoiada na história de vida de seus criadores Milton Nascimento e Márcio Borges, revela não apenas um alto grau de maturidade, nessa que é considerada por eles como sua estreia como compositores profissionais - no ano de 1964, mas também uma síntese e protótipo para muitos procedimentos e características estilísticas que se consolidaram ao longo de suas carreiras. Novena é muito importante porque, embora seja considerada pelo próprio Milton Nascimento como sua primeira composição profissional, já apresenta grande maturidade e sofisticações nos níveis da forma, harmonia, desenvolvimento motívico e relação texto-música.

A análise da relação texto-música em Novena ilustra a atenção de Márcio Borges ao conteúdo musical e seu cuidado na expressão artística, ao mudar radicalmente a letra da canção que passou de um canto ao amor para uma súplica pelos marginalizados. Revela também o cuidado de ambos o músico e o letrista de realçar elementos poéticos da letra, associando-os (1) a registros e timbres contrastantes da voz (grave e agudo, voz de peito e falsete), (2) ao contornos melódicos ascendentes, descendentes ou horizontais; (3) a um tratamento do par harmonia-melodia segundo dualidades como dissonância versus consonância e Modo Maior versus Modo modos de natureza Maior (como o Jônico ou Mixolídio) versus modos de natureza Menor (como o Dórico ou Eólio); (4) a redundâncias e repetições.

Novena revela forte influência do jazz, desde a escolha dos músicos - renomados jazzistas norte-americanos -, até a utilização de procedimentos como a valorização da música instrumental e da improvisação, passando pelo emprego da forma $A A B A$, da blue note, de empréstimos modais e de diversos tipos de re-harmonização. A análise harmônica e melódica de Novena ainda mostra a utilização de elementos normalmente associados às sensações de ambiguidade, tensão e tristeza (como mode mixture, acordes inusitados como o acorde maior-menor, acordes por empréstimo, acordes alterados e aproximações harmônicas e o predomínio da cor menor (como nos modos Dórico ou Eólio). Essa atmosfera pode ter motivado Márcio Borges a mudar o conteúdo da letra, passando de uma atmosfera mais ingênua ("A vida vem de algum lugar, para nos falar de alguma paz de um amor... ") para um clima de protesto e menos resignado ("Se digo um ai, é pelos malditos deserdados desse chão"). Outro procedimento típico de Milton Nascimento já vislumbrado em Novena é a progressão entre de acordes cujas fundamentais estão distanciadas uma terça menor uma da outra.

Se a influência do filme Jules e Jim de Truffaut não se traduziu diretamente na absorção de materiais musicais de sua trilha sonora, permeou a estética e a maneira de compor música e letra por Milton Nascimento e Márcio Borges: o não convencionalismo. Novena também permite estabelecer um paralelo entre o fato dos dois atores protagonistas e grandes amigos do filme terem uma musa e pivô - Jeanne Moreau - e a grande amizade cultivada entre Milton Nascimento e Márcio Borges, que também escolheram uma outra musa como pivô de sua relação: a música.

\section{Referências de texto}

ADOUR DA CÂMARA, Fábio. Sobre Harmonia: Uma Proposta de Perfil Conceitual. Belo Horizonte, Universidade Federal de Minas Gerais. (Tese de Doutorado em Música), 2008.

BORGES, Márcio. Entrevista de Márcio Borges concedida a Wilson Lopes. Belo Horizonte, 19 de março de 2010.

Márcio Borges. In: Museu Clube da Esquina. Depoimento de Márcio Borgs. http://www.museuclubedaesquina.

org.br/museu/depoimentos/marcio-borges/ (Acesso em 11 de julho, 2012). 2012.

Os sonhos não envelhecem: Histórias do Clube da Esquina. 2.ed. São Paulo: Geração Editorial, 1996.

BORGES, Márcio; NASCIMENTO, Milton. A Família cresce e Bituca desiste de ser economista. In: Milton Nascimento por Bituca: e vice-versa. Capítulo 6 da coleção Milton Nascimento: uma travessia de sucesso, produzida por Seleções Reader's Digest. http://www.museuclubedaesquina.org.br/museu/depoimentos/milton-nascimento (Acesso em 09 de julho, 2012). 2012a.

. A Marca da originalidade. In: Milton Nascimento por Bituca: e vice-versa. Capítulo 8 da coleção Milton Nascimento: uma travessia de sucesso, produzida por Seleções Reader's Digest. http://www.museuclubedaesquina. org.br/museu/depoimentos/milton-nascimento (Acesso em 09 de julho, 2012). 2012b.

Epílogo. In: Milton Nascimento por Bituca: e vice-versa. Epílogo da coleção Milton Nascimento: uma travessia de sucesso, produzida por Seleções Reader's Digest. http://www.museuclubedaesquina.org.br/museu/depoimentos/ milton-nascimento (Acesso em 09 de julho, 2012). 2012c.

Introdução. In: Milton Nascimento por Bituca: e vice-versa. Introdução da coleção Milton Nascimento: uma travessia de sucesso, produzida por Seleções Reader's Digest. http://www.museuclubedaesquina.org.br/museu/ depoimentos/milton-nascimento (Acesso em 09 de julho, 2012). 2012d. 
Meninos tocando clandestinos. In: Milton Nascimento por Bituca: e vice-versa. Capítulo 7 da coleção Milton Nascimento: uma travessia de sucesso, produzida por Seleções Reader's Digest. http://www.museuclubedaesquina. org.br/museu/depoimentos/milton-nascimento (Acesso em 09 de julho, 2012). 2012e.

. Nos bares da vida. In: Milton Nascimento por Bituca: e vice-versa. Capítulo 9 da coleção Milton Nascimento: uma travessia de sucesso, produzida por Seleções Reader's Digest. http://www.museuclubedaesquina.org.br/museu/ depoimentos/milton-nascimento (Acesso em 09 de julho, 2012). $2012 \mathrm{f}$.

. Pais adotivos: música e astronomia. In: Milton Nascimento por Bituca: e vice-versa. Capítulo 4 da coleção Milton Nascimento: uma travessia de sucesso, produzida por Seleções Reader's Digest. http://www.museuclubedaesquina. org.br/museu/depoimentos/milton-nascimento (Acesso em 09 de julho, 2012). 2012g.

. Surge o compositor. In: Milton Nascimento por Bituca: e vice-versa. Capítulo 11 da coleção Milton Nascimento: uma travessia de sucesso, produzida por Seleções Reader's Digest. http://www.museuclubedaesquina.org.br/museu/ depoimentos/milton-nascimento (Acesso em 09 de julho, 2012). 2012h.

Uma família eclética. In: Milton Nascimento por Bituca: e vice-versa. Capítulo 5 da coleção Milton Nascimento: uma travessia de sucesso, produzida por Seleções Reader's Digest. http://www.museuclubedaesquina.org.br/museu/ depoimentos/milton-nascimento (Acesso em 09 de julho, 2012). 2012i.

Vinícius e Berimbau. In: Milton Nascimento por Bituca: e vice-versa. Capítulo 10 da coleção Milton Nascimento: uma travessia de sucesso, produzida por Seleções Reader's Digest. http://www.museuclubedaesquina.org.br/museu/ depoimentos/milton-nascimento (Acesso em 09 de julho, 2012). 2012j.

ESTADO DE MINAS. Foto do show de Milton Nascimento, Ron Carter e Wayne Shorter no Festival Tudo é Jazz. In: Jornal Estado Minas/Caderno EM Cultura.14 de setembro, 2008.

FILHO, Luiz Maciel. Uma parceria indesejada. In: Milagre dos peixes. Coleção Milton Nascimento. Ed. Roberto Civita. São Paulo: Editora Abril, 2012. (CD de áudio e encarte).

LOPES CANÇADO, Wilson. 2010. Novena, Crença e Gira Girou

de Milton Nascimento e Márcio Borges: análise de suas três primeiras composições criadas em uma noite de 1964 . Belo Horizonte: UFMG, 2010. (Dissertação de Mestrado).

MELLO, Luiz Antonio. Saudade de Jules et Jim ou "Uma Mulher para Dois". In: Coluna do LAM: jornalismo, cultura pop e música por Luis Antonio Mello. http://colunadolam.blogspot.com/2011/11/saudade-de-jules-et-jim-ou-uma-mulher. html. (Acesso em 09 de julho, 2012).

NASCIMENTO, Milton. Entrevista de Milton Nascimento concedida a Wilson Lopes. Belo Horizonte, 29 de setembro de 2009.

. Milton Nascimento. Site oficial. http://www.miltonnascimento.com.br. 2012 (Acesso em 11 de julho, 2012).

Telefonema de Milton Nascimento para Wilson Lopes de Nova lorque para Belo Horizonte. Outubro de 1993.

Posfácio. Rio de Janeiro, 15 de julho de 1996. In: Os sonhos não envelhecem: Histórias do Clube da Esquina. São Paulo: Geração Editorial, 1996. p.357-358.

REVISTA E ONLINE. De Minas para o mundo: marco na história da MPB, o disco Clube da Esquina, de Milton Nascimento e Lô Borges, completa 37 anos de revolução sonora. Revista e online. n.144, maio, 2009. Portal do Sesc. In: www.sescsp. org.br/sesc/revistas (Acesso em 5 de abril, 2013).

RODRIGUES, Mauro. O modal na música de Milton Nascimento. Rio de Janeiro, Conservatório Brasileiro de Música. Dissertação (Mestrado em Música), 2000.

SZAJMAN, Abram (ed.). De Minas para o mundo: marco na história da MPB, o disco Clube da Esquina, de Milton Nascimento e Lô Borges, completa 37 anos de revolução sonora. In: Revista É online. n.144. São Paulo: SESC, 2009. http://www.sescsp.org.br/sesc/revistas/revistas_link.cfm?Edicao_Id=341\&Artigo_ID=5271CtIDCategoria=6044\&refty pe=2. (Acesso em 09 de julho, 2012).

\section{Referências de áudio e vídeo}

GUEDES, Beto. Novena. In: Amor de Índio. Com Beto Guedes (voz), Milton Nascimento (violão), Luiz Alves (baixo), Robertinho Silva (bateria e tumbadora), Wagner Tiso (órgão, orquestração e regência). Rio de Janeiro: EMI, Odeon, 1978. (CD 748141-2).

NASCIMENTO, Milton; BORGES, Márcio. Novena. In: Angelus. Com Milton Nascimento (voz e violão); Herbie Hancock (piano), Pat Metheny (guitarra), Jack Dejohnette (bateria), Ron Carter (contrabaixo) e Naná Vasconcelos (percussão). Rio de Janeiro: Warner, 1993. (CD 65057040).

TRUFFAUT, François. Jules e Jim: uma mulher para dois. Com Jeanne Moreau, Henri Serre e Oskar Werner. Roteiro de François Truffaut e Jean Gruault. Música de Georges Deleru. Direção de François Truffaut. Baseado no romance homônimo de Henri-Pierre Roché. Paris: Les Films Du Carrosse / Sédif Productions, 1962. (DVD de filme).

WISNIK, José Miguel. O Som e o sentido: uma outra história das músicas. 2a ed. São Paulo: Companhia das Letras, 1999. 


\section{Referência de partitura}

NASCIMENTO, Milton; BORGES, Márcio. Novena. Lead sheet transcrita e editada por Wilson Lopes a partir da gravação no disco Angelus. In: Per Musi, v.30, p.40-42. Belo Horizonte: UFMG, 2013.

\section{Notas}

1 Mais recentemente, em entrevista a Luis Antonio MELLO (2012), Milton Nascimento declarou que viu [o filme] Jules e Jim muitas vezes mais: "Milton me disse uma vez que assistiu ao filme mais de 30 vezes. Nada demais, pois já assisti a 'Beleza Americana' umas 40."

20 crédito das fotos dos Exs.1, 2 e 3 (BORGES, 1996, p.3364-365, 366-367, 363) é dado coletivamente a Cafi, Juvenal Pereira, Leonardo Machado Costa e Marcelo Ferrari, não especificando o autor de cada uma.

3 Ao fazer parte dos W's Boys, Milton passou a ser chamado anedoticamente de Wilton, para ter um nome começando com "W", como os demais membros do conjunto: Wagner, Waltinho, Wayne e Walton (Dalton).

4 Márcio BORGES (2012) relata que sua aproximação com a marginalidade o acompanha desde e infância: "Eu era um moleque de rua, e era moleque mesmo; sempre tive uma grande atração pela coisa marginal, pelos pobres, pelos filhos das putas".

5 Wilson Lopes, segundo co-autor do presente artigo e que tem sido o guitarrista de Milton Nascimento nos últimos 20 anos, foi encarregado pelo cantor-compositor de transcrever suas músicas a partir de suas gravações, criar suas lead sheets detalhadas e publicar seu primeiro songbook completo.

6 falsete e a voz de peito são os dois tipos principais de emissão da voz masculina que, devido à ênfase em parciais específicas da série harmônica, resultam em dois timbres muito distintos.

7 José Miguel WISNIK (1999, p.160) diz que "Modernamente, o jazz será uma fonte de cruzamentos entre a harmonia tonal e as variações escalares modais, ocorrendo também esses cruzamentos em outros gêneros de música popular, de Beatles a Elomar, de Milton Nascimento a Miles Davis.

Fausto Borém é Professor Titular da Escola de Música da Universidade Federal de Minas Gerais (UFMG), onde criou o Mestrado e a Revista Per Musi e organizou diversos eventos nacionais e internacionais. É pesquisador do CNPq desde 1994 e seus resultados de pesquisa incluem dois livros, três capítulos de livro, dezenas de artigos sobre práticas de performance e suas interfaces (composição, análise, musicologia, etnomusicologia e educação musical) em periódicos nacionais e internacionais, dezenas de edições de partituras e recitais nos principais eventos nacionais e internacionais de contrabaixo. Recebeu diversos prêmios no Brasil e no exterior como solista, teórico, compositor e professor. Acompanhou músicos eruditos como Yo-Yo Ma, Midori, Menahen Pressler, Yoel Levi, Fábio Mechetti, Arnaldo Cohen e músicos populares como Hermeto Pascoal, Egberto Gismonti, Henry Mancini, Bill Mays, Kristin Korb, Grupo UAKTI, Toninho Horta, Juarez Moreira, Tavinho Moura, Roberto Corrêa e Túlio Mourão. Editou os números 22, 23, 28, 29 e 30 da Revista Per Musi, conjunto com mais de 1.000 páginas de trabalhos acadêmicos dedicados à pesquisa sobre música popular.

Wilson Lopes é Professor de Violão/Guitarra Popular da Escola de Música da Universidade Federal de Minas Gerais, onde obteve o Bacharelado em Música (2006) e o Mestrado em Música (2010). É parceiro musical e guitarrista da banda do compositor/cantor Milton Nascimento desde 1993. Entre turnês nacionais e internacionais gravou nos discos Angelus (1993), Nascimento (1997), Milton e Gil (2000), Pietá (2002) e Milton e Belmondo (2008). Paralelo ao trabalho com Milton, mantém uma carreira solo e hoje conta com seis discos autorais gravados: 1- Lua (Grupo Edição Brasileira) 1989; 2 - Nossas Mãos - Duo de Violões "Homenagem a Milton Nascimento" (Wilson Lopes e Beto Lopes) 1999; 3 - Estórias do Dia (Wilson lopes) 2001; 4 - Nossas Mãos - Duo de Violões "Homenagem ao Clube da Esquina"(Wilson Lopes e Beto Lopes) 2004; 5 - Tempo Maior (Wilson Lopes) 2006; 6- Nossas Mãos - Duo de Violões "Homenagem a Toninho Horta" (Wilson Lopes e Beto Lopes) 2008. 